\title{
The Development of Instruments to Measure Student Mathematical Logical Thinking Ability in Kapita Selekta
}

\author{
Novaliyosi ${ }^{1}$ \\ 1) Pendidikan Matematika, FKIP, Universitas Sultan Ageng Tirtayasa, Serang, Banten, Indonesia
}

\begin{abstract}
The ability of logical thinking mathematically is one of the goals of the learning of mathematics, namely forming ability of reasoning students that reflected his skills in critical thinking, logical, systematic, and objective nature, honest, discipline in solving a problem well in various fields. In addition math can form a mindset into a mindset of mathematical, logical, systematic and critical that can be used to solve problems in daily life. This research aims to develop a test instrument for measuring the ability of logical thinking mathematically students on kapita selekta. The development method used in this research is to include: (1) define the variable; (2) outlines the variables into a more detailed indicators/dimensions; (3) draw up the details; (4) perform validation; (5) conducting trials; (6) analyze of validity and reliability. Based on the results of the test in theoretic instruments that developed included into the category is valid and worthy to be used on next stages as an instrument to measure the ability of logical thinking mathematically.
\end{abstract}

Keywords: Instruments, Mathematical Logical Thinking.

\section{INTRODUCTION}

Learning mathematics aims at forming ability of students reasoning that reflected his skills in critical thinking, logical, systematic, and objective nature, honest, discipline in solving a problem either in various fields (Widdiharto, 2004). Mathematics can form a mindset into a mindset of mathematical, logical, systematic and critical that can be used to solve problems in daily life (Tiurlina). In line with the opinion, there are two development direction about the nature of mathematics education, development to the needs of the present leads to an understanding of the concepts needed to solve the problem of mathematics and other sciences and the time will come that make learning math can give the ability of reason and logical, systematic, critical thinking, and careful and objective and open (Sumarmo, 2002).

Commitee on the Undergraduate Program in Mathematics (CUPM) (2004) describes the six basic recommendations for majors, programs, and all courses in mathematics. One of them explains about the development of the ability of analysis, critical reasoning, logical thinking, problem solving, communication and mathematical representation can be formed through courses in mathematics. Therefore already for colleges that produce prospective educators (teachers) which is in charge of teaching mathematics is responsible for preparing the student to improve mathematical ability as one of the factors cause the failure of education in building national character are educators.

Students majoring in mathematics education as a prospective educators (teachers) should be aware that they have a strategic role in the formation of the next generation a nation that not only has the intelligence of a brain but also a good character. In this case the brain intelligence indicators which were learned, think logically and critically. Need to be developed so that the ability of logical thinking ability of the students in this case can think logically and systematically.

Think logically give full confidence to say something because everything that is said to be based on a logical reason as well as the support of strong evidence. It makes a person can get the truth, because it has been through the process of formulating and evaluating their own beliefs and opinions are systematically. Logical thinking allows one to evaluate the evidence, logic, and language that underlies the statement of others privately organized. Through math problem solving, logical thinking ability could be developed because math is a tool to develop the ability to think. One of the ability of thinking that can be developed in the process of problem solving student is logical thinking.

Logical thinking ability is closely related to the activities of problem solving. This is in accordance with the opinion of the Tuna, Cagri Biber \& Incikapi (2013) stating "activities requiring such critical skills USA, creative problem solving, critical and reflective thinking would also improve teacher candidates ' logical thinking ability". In addition, according to the Yaman (2005) one of the cognitive skills that affect the academic success of students is the ability to think logically. Logical thinking ability based on individual expertise to solve the problem by using its ability to achieve the principles or rules by making generalizations or abstractions. So it needs to be a logical thinking ability students as prospective teachers is enhanced through some activity that demands critical skills include problem solving, creative thinking, critical and reflective. The more frequently involved in the activity of problem solving, logical thinking ability of the students will be getting better.

1 Corresponding author: chi_2409@yahoo.com 
Based on that assumption, it will test the ability of the instrument developed logical thinking for students on kapita selekta.

\subsection{Research Question}

Based on the above description, the reserach question is "How to develop the instrument of mathematical logical thinking ability in Kapita Selekta?" The problems studied are:

a. The developed instrument is the mathematical logical thinking ability.

b. The topic are comparison, probability, combinatorics and mathematical logic.

\subsection{Aims}

Based on the above description, the aims of this study are:

a. To develop instrument mathematical logical thingking ability in Kapita Selekta

b. To develop instrument that can measure students' mathematical abilities on the topic of comparison, probability, combinatorics and mathematical logic of first students at the university.

\section{METHODS}

This research aims to produce an instrument tests the ability of logical thinking on mathematical subjects was kapita selekta topics comparison, opportunities, combinatorics, logic and mathematics. The instruments developed can be used in the process of the lecture so that the research will be carried out is research development (Development Research) that a heavy emphasis is the development of the instrument. According to Ruseffendi (2005:32), research development (Development Research) is a research to develop and produce products educational material, media, tools and learning strategies, or evaluation, and so on to cope with the problems of education, and not to test the theory.

Research development of procedure consists of two stages, namely to develop instruments and test the quality and effectiveness of the instruments or produced. The first stage is to develop instruments include: (1) define the variable; (2) outlines the variables into a more detailed indicators/dimensions; (3) draw up the details; (4) perform validation; (5) conducting trials; (6) analyze validity and reliability.

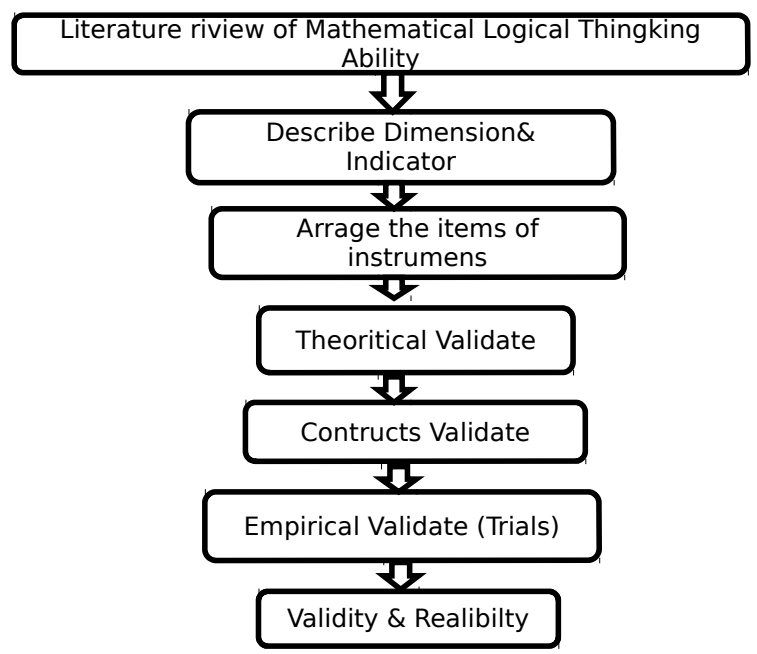

\section{Diagram 2.1 Stage of Develop Instrument}

\section{RESULTS AND DISCUSSION}

This section will describe the results that have been achieved during the study, but the new results are achieved is an instrument that's been validated by experts and panelists theoretically. The following is a breakdown of the results that have been achieved.

Mathematical logical thinking capability of the Instruments

The instruments that have been produced in this research are mathematical logical thinking ability of instruments consisting of 5 packages of instruments the logical mathematical thinking ability. Package instruments this mathematically logical thinking capability will be used to 4-5 times the ability test logical thinking 
mathematically selekta capita of lectures at the time. As for the definition of logical mathematical thinking ability is the ability of the student in resolving the matter in the form of a description based on several indicators, namely: 1) Think proportional i.e. thinking ability in determining and comparing the ratios. 2) Think the probability of that is the ability to interpret the data obtained in the form of the magnitude of the probability of an event. 3) Think correlational i.e. the ability in determining whether two events/variables are related or not. 4) Think Combinatorial, namely the ability to determine the combination of the likelihood of an occurrence.

These instruments display problems such as logical mathematical thinking ability in accordance with the indicators, which consists of the following topics: 1) Comparison 2) Probability 3) mathematical logic 4) Combinatorics

Here are parts of the display of each topic on the instrument's ability to think mathematically logical.

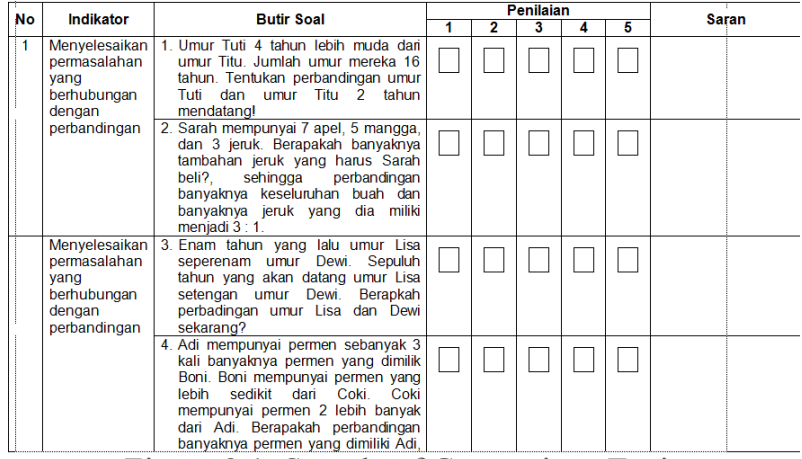

Figure 3.1. Sample of Comparison Topic

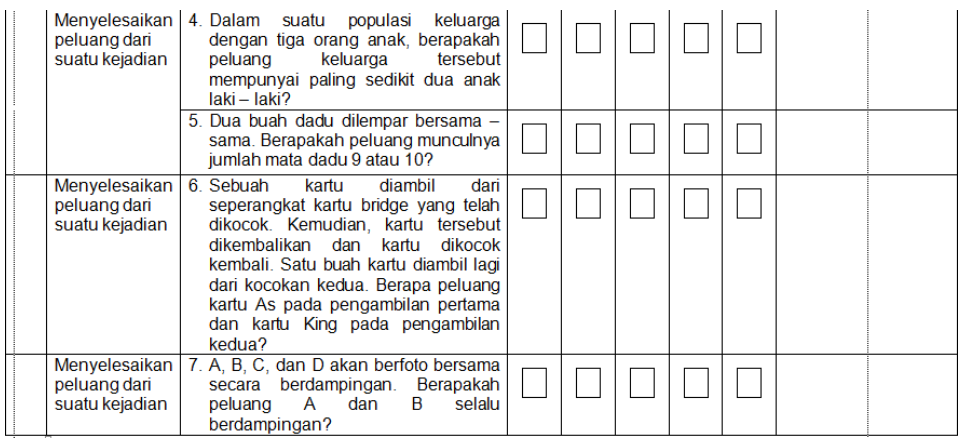

Figure 3.2. Sample of Probability Topic

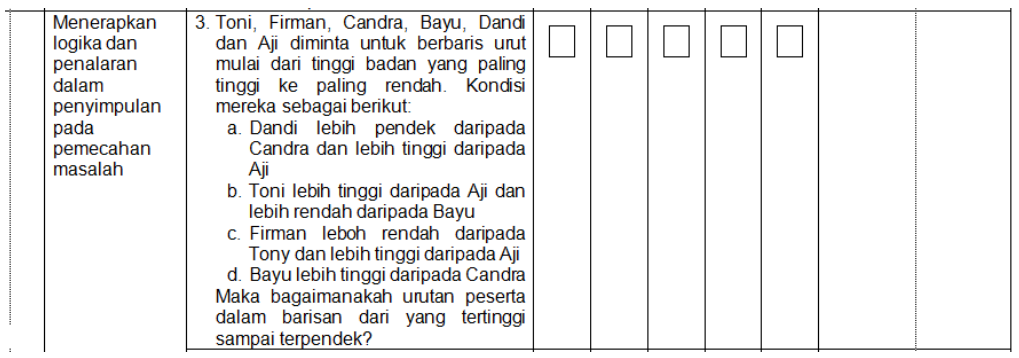

Figure 3.3. Sample of Mathematics Logic Topic

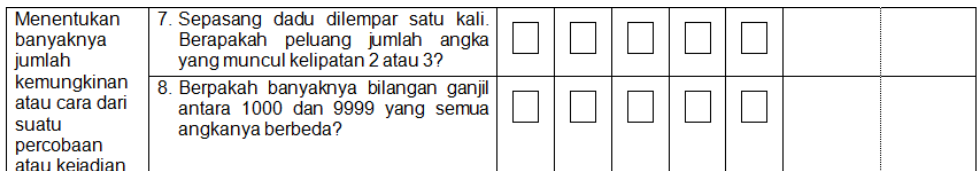


Figure 3.4. Sample of Combinatoric Topic

The instrument was drawn up on the basis of indicators of the ability to think mathematically logical. From the initial design of logical thinking ability of mathematical instruments that have been produced, then conducted testing or validation of theoritically to the panelists and experts.

\section{Results of the validation of the Panelist and Expert}

Table 4.1 Result of Validation Theoretical Instruments

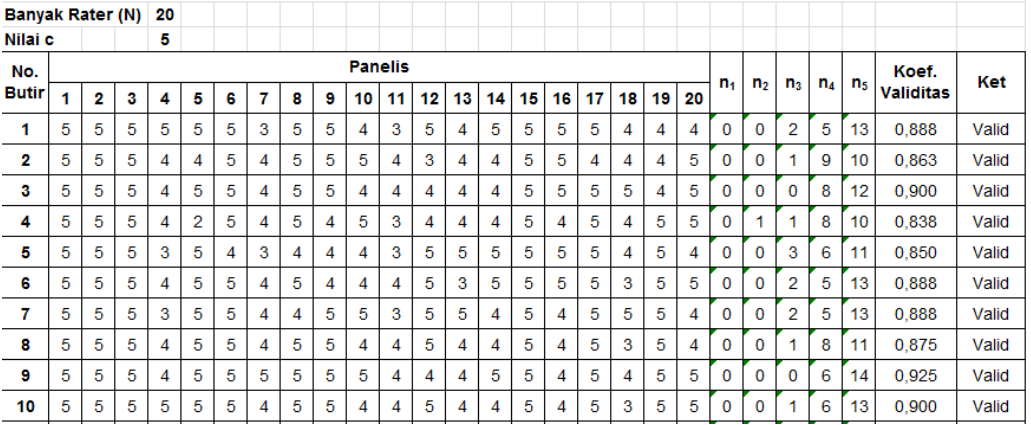

etc

Following are the results of the validation test the contents of the instruments carried out by the panelists. Panelists in this test as many as 20 people are comprised of professors and teachers. Based on the calculation of test acquired the above validity coefficients 0.2 . This shows the instruments developed as many as 40 grains of matter is valid and deserves to be used in the next step as a test instrument for measuring the ability of logical thinking students.

\section{CONCLUSIONS}

Based on the results of the expert and expert panelists validation indicates that the instrument is designed easy to read and well understood by the student with some improvements of the sentences and language without reducing the content and meaning. The results of the validation of the content in teoritik indicates that the instrument developed logical thinking ability contains the category is valid and worthy of use for later stages as an instrument to measure student mathematical logical thinking ability in kapita selekta.

Some advice that can be given for improvement the next development is as follows:

1) The material in the development of this instrument is limited to just the courses kapita selekta, should cover other subjects

2) Mathematical logical thinking Ability) who emphasized on 4 topics only, so that in the future should be developed on another topic.

\section{REFERENCES}

1. Rachmadi, Widdiharto, Model-model Pembelajaran Matematika SMP, (Yogyakarta: Widyaiswara PPPG Matematika, 2004).

2. Tiurlina, Hakikat Matematika dan Pembelajarannya di SD. http://file.upi.edu/Direktori/DUALMODES/MODEL_PEMBELAJARAN_MATEMATIKA/HAKIKAT_MATEMATIKA.pdf (diakses 2 Januari 2017).

3. Utari Sumarmo, 2002, "Alternatif Pembelajaran Matematika dalam Menerapkan Kurikulum Berbasis Kompetensi”, (Makalah pada Seminar Tingkat Nasional, FPMIPA UPI Bandung, 2002).

4. Tuna, Abdulkadir; Çagri Biber, Abdullah \& Incikapi, Lütfi. "An Analysis of Mathematics Teacher Candidates' Logical Thinking Levels: Case of Turkey", Journal of Educational and Instructional Studies in The World, February, March, April 2013, Volume: 3 Issue: 1 Article: 10 ISSN: 2146-7463.

5. Suleyman Yaman, "Effectiveness on Development of Logical Thinking Skills of Problem Based Learning Skills in Science Teaching”, (The Journal of Turkish Science Education Vol:2 Issue:1;May 2005), hh. 31-33.

6. Ruseffendi, E.T (2005). Dasar-dasar Penelitian Pendidikan dan Bidang Non Eksakta Lainnya. Bandung : Tarsito. 